\title{
Factors Affecting Performance of Trade Unions in Kenya
}

\author{
Christine Anyango ${ }^{1}$, Nelson Obange ${ }^{1}$, Evans Abeka $^{1}$, Gerald Ochieng Ondiek $^{2}$, Odhiambo Odera ${ }^{3 *}$ and \\ Mary Evelyn Ayugi \\ ${ }^{1}$ School of Business and Economics, Maseno University, Kenya \\ ${ }^{2}$ School of Business, University of Nairobi, Kenya \\ ${ }^{3}$ University of Southern Queensland, Australia \\ ${ }^{3}$ Masinde Muliro University of Science and Technology, Kenya \\ ${ }^{4}$ Department of Sociology, University of Nairobi, Kenya
}

\begin{abstract}
Trade unions have been used to settle disputes between members and management, the implementation of changes and securing adequate representation of members in government, public and private sector. The objective of this research was to determine factors affecting performance of Kenya National Union of Teachers (KNUT). The research was a cross- sectional survey done in Nyando District, Kisumu, Kenya using structured and unstructured questionnaire administered to KNUT officials and the teachers. Sample size used was 352 comprising of 341 teachers and 11 KNUT officials. Face to face interview technique was adopted for this study and descriptive statistics was used to analyse the data. The findings of this research indicate that only $71.6 \%$ of the teachers are members of KNUT, the remaining $28.4 \%$ are not. The factors affecting performance of the union were observed as financial, declining membership, political interference among others and this has worsened the performance of the union in the district.
\end{abstract}

Keywords: Kenya, performance, trade union, human resource, management

\section{Introduction}

Developments that have affected labour both in quality and quantity worldwide are closely related to political, social and economic environments. Organised labour has affected the development of society and is responsible for securing workplace protections and privileges (Beardwell \& Claydon, 2007). The first unions were formed in 1700 s and their goal was to control price of skilled labour, demanding uniform rates and controlling output. Later in 1850 s and1860s, the industrial revolution saw the rise of new unions in industries.

Collective bargaining has traditionally been concerned with wage/salary determination; its scope has widened considerably over the years and today encompasses working hours, holiday's entitlement, sick pay, promotion policies and pensions. All these expectations should be met by the employer and it is the duty of union leaders to ensure that they are met. Union leaders need a reasonable membership to have their needs addressed by the employer. Membership of KNUT in the early days was mandatory for the newly employed teachers in Kenya; this enabled the union to have the numbers required by TSC to enable collective bargaining.

\footnotetext{
*Corresponding author.
}

According to Nkomo \& Cox (1996) the presence of labour union in an organization results in less management autonomy and flexibility in design and implementation of human resource management policies. Trade unions have been used to settle disputes between members and management, the implementation of changes and securing adequate representation of members in government, public and private sector. Legal assistance to members has been part and parcel of their duty. Mathis \& Jackson (2008) assert that the primary determinant of whether employees unionize is management. If management offers competitive compensation, good working environment, effective management and supervision, fair and responsible treatment of workers, they can act as antidote to unionization efforts. Unionization results when employees feel disrespected, unsafe, underpaid and unappreciated therefore they see unions as viable option. Trade unionism is seen by some to be in terminal decline and no longer relevant to an advanced society. Others believe that unionism has moved to a marginal position in employee relations and some sense of resurrection is required, based on support. Trade Unions worldwide are facing a lot of challenges. Researches done in Eastern and Western Europe have shown that Union members are not satisfied with their Unions (Georgelles \& Lange, 2010). Among the issues that have been reported in 
several states including UK, Japan, Canada and others are the declining membership, de-recognition, political manipulation of union among others. The proportion of younger people who choose to join unions has declined dramatically, suggesting that they do not see membership of collective employee body as necessary or desirable (Waddington, 2003). Generally trade unions perform significant role in employee's life and always provide checks and balances to the government regarding accountability of its leaders. KNUT in Kenya represents teachers thereby its influence on the quality of education and work life for the teachers is important and affects everybody.

Trade unions were established to protect the working life of workers. Currently they are facing varies challenges and hence weakening the unions. Some of the problems being faced by trade unions in Kenya are revolution in production technologies and new management styles. Splintering, changing mentality, mismanagement of funds, lack of innovation and visionary leadership are a big handicap. Most unions are grappling with the democratization of social and political arena besides government interference. The objective of this research was to determine factors affecting performance of Kenya National Union of Teachers (KNUT). Furthermore, education being a key sector in the economy, it becomes important to evaluate the performance of KNUT as a union.

\section{Literature Review}

A trade union is a formal association of workers that promotes the interests of its members through collective action. Employees join unions with main objective of improving their work conditions, for this reason unions have been formed from organization level to national level up to international level. Mathis \& Jackson (2008) observe that the percentage of union membership varies significantly from country to country. According to historical data, a survey of 30 countries found that since 1970, union membership percentages have increased in only 4 countries (Belgium, Denmark, Finland and Sweden). They say that union membership is falling in many advanced countries, but collective bargaining is set in law as the way wages are determined in Europe. In many European countries, artificially high wages and generous benefits have kept unemployment rate high, however the pressures for change are increasing. The range of labour concerns varies from country to country. In some countries unions do not exist at all or are relatively weak while other countries require firms that have union or worker representation on their boards of directors (Bolton \& Haulian, 2007;
Clegg et al, 2005; Ellis \& Dick, 2000; Greenberg, 2002; Mckenna \& Beech, 2002).

Decline in union recognition is a world-wide trend; survey done in UK by WIRS survey data pointed a substantial decline in union recognition. The figure for all places fell from $66 \%$ in 1984 to 53 $\%$ in 1990 (Gall \& McKay, 2004). Overall only $3 \%$ of all work places which had not recognised unions by 1990 had previously recognised unions at some stage in 1984. Torrington et al (2005) report that the main cause of trade union decline in UK is industrial restructuring. They say that established industries where union is the norm have declined because the jobs have been lost and replaced with service sector in which union membership is great deal rarer e.g. call centres, retailing and tourism. The size of the average workplace has declined too, and this has adversely impacted on the propensity of employees to join a union. According to them, there are few factories employing thousands of workers on assembly lines as before.

The question of whether continued trade union decline is inevitable has been considered by many and is one characterised by diverse views. From a trade union perspective there are grounds for pessimism, despite years of new initiatives aimed at recruiting new members in private sector. Waddington (2003) reports that in 1991 as many as $37 \%$ of people in UK in the 25 to34 age group were members of the union, ten years later the union density among under 30 s had fallen to $16 \%$, compared with $34 \%$ among those over the age of 30 .

McKenna \& Beech (2002) state that the tradition of employee representation through trade unions and collective bargaining as the focus of engagement between the management and unions is being replaced by new relationships in the workplace, but the replacement is not a single type. It is made up of a number of different trends. In some cases the traditional model is retained, in others increased individualism, and yet in other cases a partnership approach is adopted in which unions take some of the concerns of the organisation and work with management in order to maintain the profitability and longevity of the firm. Aluchio (1998) explains that that trade unions in Kenya are organised on industrial basis, this is in line with the agreement reached in 1957 between Federation of Kenyan Employers (FKE) and COTU formerly Kenya Federation of Labour. Union activities in Kenya are restricted to workers below the rank of supervisor and exclude personnel engaged in confidential, directive and administrative representational and supervisory activities of the undertaking. The trade unions have rules which must be in line with Trade Unions Act (Cap 233) of the laws of Kenya. All the unions must have aims and 
objectives, state areas the union is to represent, category of workers to be members, membership fee and monthly contribution fee, provision for honorary membership and other rules.

According to Mathis \& Jackson (2008) there exists an adversarial relationship between unions and management that sometimes leads to strikes and lockouts. However, such conflicts are relatively rare. What is important between the management and unions is recognition by both parties. Major concern for employees is recognition, in terms of respect, esteem and approval of others. Indeed lack of recognition often creates loss of esteem and motivation. Armstrong (2006) gives factors that determine recognition or de-recognition. One of the factors is the perceived value or lack of value of having collective bargaining. The second factor is the extent to which the management has freedom to manage the unions and the third factor is the history of relationship with the union. The fourth factor is the number of union members and the proportion of employees who are members. The fifth factor is the preference to a particular union.

Trade unions are seen to be in partnership with the employers although this has been with element of pragmatism, recognising that the new unionisms seem to be moderate and conciliatory to maintain support from employers and the state. Beardwel \& Claydon (2007) contend that the concept of social partnership can be questioned if not supportive of the managers or employers. However critiques of concept of social partnership questions the feasibility of such relationships. Kely (1996) argues that it is difficult to form meaningful relationship with a party who wishes you did not exist.

Bacon \& Storey (1996) argue that partnership initiatives have been frustrated in a number of firms, owing to the lack of management commitment to the process leading to nothing more than rhetoric of partnership. According to Armstrong (2007), partnership may not work if senior management does not really believe in partnership and decisions are made unilaterally without consulting trade union officials. Mosley et al (1996) observe that leadership is a process of influencing individual and group activities towards goal setting and achievement. Beardwell \& Claydon (2007) explains that a number of bargaining initiatives have emerged during the 1980s which have changed the level and structure of collective bargaining. The initiatives have facilitated the exercise of managerial prerogative in the bargaining relationship and further narrowed the scope of bargaining channels. Mathis \& Jackson (2006) state that unions in some countries are closely tied to political parties. In Italy and France, national strikes occur regularly to protest proposed changes in government policy on retirement, pension and regulations regarding dismissal of employees

\section{Methodology}

The study was a cross- sectional survey descriptive in nature. Survey is viewed as being suited for descriptive research (Sekaran, 2006; Luck \& Rubin, 1987). The approach is effective in handling research which needs information from different people and for convenience of comparison. Since the entire population of interest was not be covered, a cross sectional survey was justified as this approach allows generalization of findings and is representative. The population constituted teachers both in primary and secondary schools and also KNUT officials in former Nyando District, Kisumu, Kenya. A total population of 3000 teachers exist in the study area inclusive of KNUT officials.

The study adopted stratified random sampling. The study stratified teachers on the basis of primary, secondary school teachers and KNUT officials. The sample frame constituted 341 teachers and 11 KNUT Officials. The sample size of 352 respondents was used in this study. The sampling was done in stages, stage one involved stratification into primary and secondary school teachers. Within the strata simple random sampling was used to select the respondent which was stage two of the process. Sampling frame consisted of list of all schools in Nyando and a list of KNUT officials. Within the schools respondents were teachers selected based on convenience. Face to face interview technique was adopted for this study and descriptive statistics was used to analyse the data.

\section{Results and Discussion}

The research sought from respondents when they regard a union to be performing. Findings reveal that most members feel union is performing when there is a strike; this is due to the fact that all salary increments have been achieved in Kenya when union leaders call a strike. To other respondents, unions were performing when they negotiate salary increments. While to other respondents, unions perform when they address all issues affecting their members.

Trade unions just like any other organization must have certain performance variables. The research sought to find out how the variables are important to the union using a 5 point scale starting from not important (1) to very important (5). The union officials were asked how important the following variables were in determining performance of a union: large membership, union recognition, finance, negotiation skills, partnership, leadership and communication. 
Table 1: Performance variables as a percentage.

\begin{tabular}{lccrrc}
\hline Performance variables & Not Important & Less Important & Indifferent & Important & Very Important \\
\hline Large Membership & 0 & 0 & 0 & 18.20 & 81.20 \\
Union Recognition & 0 & 0 & 0 & 18.20 & 81.80 \\
Finance & 0 & 0 & 0 & 18.80 & 81.20 \\
Negotiation skills & 0 & 0 & 0 & 0 & 100 \\
Partnership & 0 & 0 & 9.10 & 9.10 & 81.80 \\
Leadership & 0 & 9.10 & 0 & 9.10 & 81.80 \\
Communication & 0 & 0 & 0 & 0 & 100 \\
Average & 0 & 1 & 1 & 10.49 & 86.83 \\
\hline
\end{tabular}

Most of the respondents considered the variables to be very important for them. $86.8 \%$ of respondents were for the idea that large membership, recognition, finance, partnership, leadership and communication are core variables to union's good performance.
When teachers are on strike everybody in the country is affected directly or indirectly, this makes them influence TSC to yield to demands. Recognition of the union by the employer is very important for any negotiation to take place between the two parties.

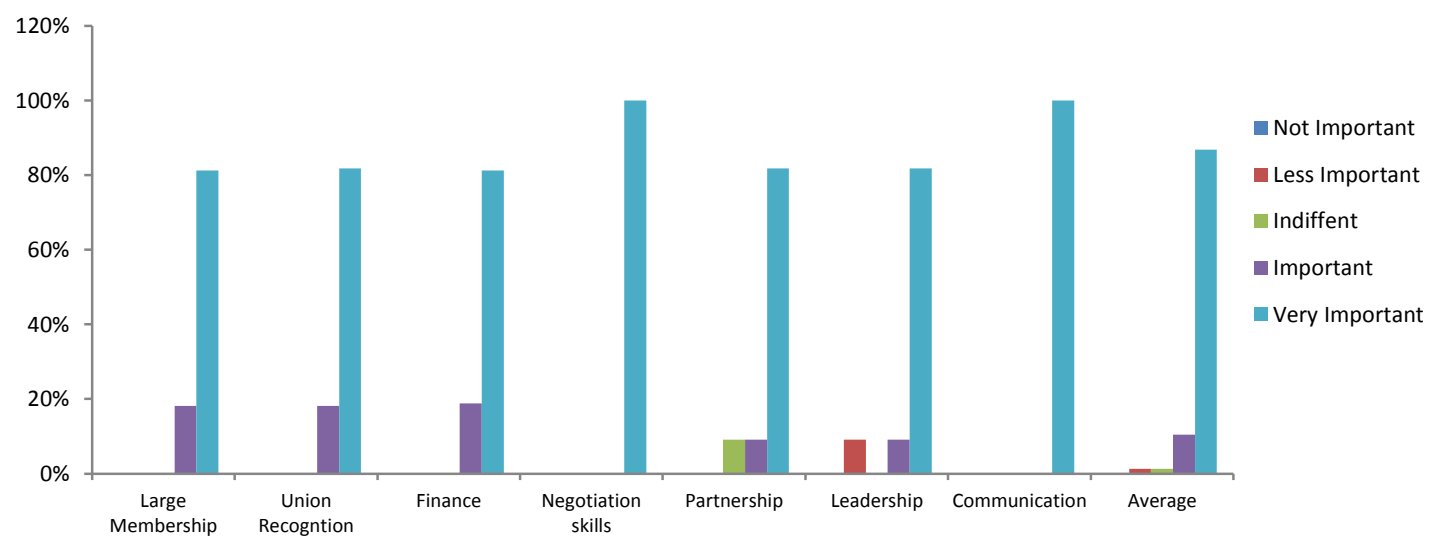

Figure 1: Performance Variables.

Respondents also gave finance as a major determinant of performance. Finances are needed to train union leaders to deliver and also to meet daily expenses. $81.8 \%$ felt that finances were very important for all the activities of the union. Negotiation skills were also considered very important, all the respondents had a feeling that it was a very important aspect in achievement of goals. Partnership with other unions performs an important role in understanding the trends of unions worldwide. Unions usually support each other financially and ideologically so unions should not be independent. Partnership with the employer is important because it ensures that union is involved in decisions that will affect members. People and organizations are understood well when they communicate effectively to others. Both the union officials and members need to communicate effectively so that their efforts are understood by either party. Every aspect of management requires effective communication. Respondents were asked how often they interact with members. Most respondents confirmed that they do not interact with members quite often. Poor interaction is a major weakness which is capable of ruining the union. When a union is not communicating effectively with the members, they are likely to misunderstand their union. Constant communication with members ensures that members do not complain because they understand their union. The challenges facing KNUT according to members was found to be the following, political manipulation where politicians use the unions for own political gains. The second challenge was financial problems where member's contribution was not enough to carry out desired activities of the union. Lack of training to members was considered a challenge since this created discontent among members because they do not understand activities of the union. Some of the members were not even aware of how unions can assist them, they do not know what problems to take to unions and end up blaming unions for everything. 


\section{Conclusion}

Findings of the research are that $63.8 \%$ of nonmembers are those who are young actually in the age group 20-29. The solution to raising union membership is serious recruitment campaigns in all divisions. This will reduce problems like lack of awareness and indecisiveness among the newly employed teachers. Most of the respondents are not satisfied with their unions. Salaries is a major concern for many, is the delayed salary increment which had been promised by TSC in 1997 . To most teachers KNUT leaders are after adequate payments and allowances at the expense of their members. Teachers cited promotions of heads as irregular and not on the basis of performance and experience. While most of the members accept that unions are necessary in any work environment, they claim that officials have not worked devotedly to make their lives better. The feeling of dissatisfaction among members can be overcome by proper communication between union officials and their members. The study found that financial problem was a major challenge to the union. According to the officials, they lack finances even to maintain a branch office. The finances provided to pay rent, pay workers at the office, electricity and other expenses was inadequate. The only source of finance is member's contribution, of which a percentage of it is taken up by the headquarters for maintenance; a small percentage is given to branch to pay the secretary who is the only official sitting at the office. The union is planning to increase membership for all members to make it financially stable.

Another major challenge is the rival union like Kenya Union of Post Primary Education Teachers (KUPPET) which is attracting members to join and leave KNUT. The rival union contributes to the challenge of finances as it leads to reduction of members' contribution. According to the KNUT officials, when there are negotiations for salary increment, then the rival union accepts less percentage. The similar situation was experienced in February 2009 when other unions like KUPPET accepted a salary increase that was below the expectations of KNUT. According to KNUT, unions like KUPPET are political tool being used by the Teachers Service Commission (TSC) to undermine teachers. To overcome the emerging presence of other unions such like KUPPET, the union should be aggressive in promoting its objectives in order to be attractive to most people.

Proper communication with members will make them understand activities of the union, union's achievements and challenges so that the unions are not seen to be ineffective but an integral part of the teachers. KNUT should target those not yet employed by the government this will help in popularising the union. Any organization needs a good conducive environment to perform. The study recommends that there should be effective communication between the union and members because it seems there is misunderstanding between the two, while unions are negotiating for salary increment, members do not recognise their efforts. To the members, unions are working when they call strike for the members.

\section{References}

Aluchio, L. P.A. (1998) Trade Unions in Kenya Jomo Kenyatta Foundations, Nairobi Kenya

Amstrong, M. (2006) Human resource management practice, 10th Edition Cambridge University Press, UK

Bacon, S. \& Storey, M. (1996). Individualism and collectivism in ackers, the new workplace and Trade Unionism Routledge, London

Beardwell, J., \& Claydon, T. (2007).Human resource management: a contemporary approach. Pearson Education

Bolton, S C. \& Haulihan, M. (2007) Management, work and organisations, Searching for the human in HRM, Palgrave Macmillan, New York

Clegg, S., Berger, M. K. and Pitsis, T. (2005) Managing and organisations; An Introduction to Theory and Practice Sage Publications Limited

Elli, S. \& Dick, P. (2000) Introduction to organization behaviour, McGraw Hill Publishing company

Gall, G. \& McKay, S. (2004) Trade Union recognition in Britain 1995-02: Turning a corner Industrial Relations Journal 35, 3, 249-270

Georgellis, Y \& Lange, T. (March 2010) Are union members happy after all? Evidence from Eastern and Western European Labour Markets

Greenberg, J. (2002) Managing behaviour in organisations, Prentice Hall

Luck, D. J. and Rubin, R.S. (1987). Marketing Research, 7th Edition, Englewood Cliffs: Prentice-Hall

Kely, J. (1996) union Militancy and Social partnership London: Routledge.

Mathis, R. L. \& Jackson, J. (2008).Human resource management, $12^{\text {th }}$ Edition Thomson South Western

McKenna, E. and Beech, N. (2002). Human resource management, Prentice Hall

Mosley, N., Pietri, L. and Meggison, D. (1996) Leadership. Principles and practice Prentice hall New York

Nkomo, S. \& Cox, T. (1996). Diverse identities in organizations In Clegg, S.R., Hardy, C. and Nord, W.R. (eds) Handbook of Organization Studies, pp. 338-56. London: Sage.

Sekaran, U. (2006). Research methods for business, A Skill-Building Approach Nutech Photolithographers, New Delhi, India

Torrington, D., Hall, L. and Taylor, S. (2005) 'Human resource management $(2005) 6^{\text {th }}$ Edition. Prentice Hall, England

Waddington, J. (2003). What do representatives think of the practices of european works councils? Views from six countries. European Journal of Industrial Relations 9(3): 303-32 